Robinson, R., Martins, A., Solnet, D. and Baum, T. Journal of Sustainable Tourism

Accepted $12^{\text {th }}$ October 2018

\title{
Sustaining Precarity: Critically examining tourism and employment
}

\begin{abstract}
There is consensus that the social, or people, dimension of sustainability including its workforce thematics are neglected in the tourism literature and policy despite its prevalence in the Sustainable Development Goals (SDG). Premised on the understanding that sustainability is inherently set in neo-liberal discourses of progress, development and growth, we set about to investigate tourism's performance principally relative to SDG, no. 8 (UN, 2015), which calls for 'decent work'. Underpinned by precarity, an emerging sociological concept applied in the workforce context, and adopting critical approaches, this paper presents a review of a sample of industry reports from global, regional and national levels. The study provides evidence that tourism sustains precarity vis-à-vis its employment practices. Our findings suggest that, counter to prevailing sustainability discourse, tourism (employment) sustains deep social cleavages and economic inequalities - a triumvirate of precariousness of work, precariousness at work and subsequent precariousness of life.
\end{abstract}

Keywords: precarity, sustain, employment, workforce, humanist, social exclusion theory 


\section{Introduction}

Shared understandings of sustainability are inherently set in neo-liberal discourses of progress, development and growth. As part of the market economy, tourism (whether branded as sustainable or not) is entangled in "an aggressive economic liberalism" (Bianchi, 2009, p.493). This notion is exemplified and amplified by Sustainable Development Goal, no. 8 (United Nations, 2015), which calls for 'decent work and [simultaneously] economic growth', and whose targets call for 'economic growth', 'higher levels of economic productivity', 'development-orientated policies', 'improve progressively', 'expand access to banking' - in other words a developmental process (Melissen, 2013). Yet literal definitions of sustain(ability), capture less assumptive, assertive and/or developmentally ambitious objectives; inter alia 'to hold', 'to strengthen', 'continue', and to 'maintain'. As Melissen (2013) suggests, sustainability in itself is a stasis, or stage - possibly the end product of sustainable development. Regardless, this paper assumes these less fully laden designations in a critical investigation of the inter-relationships between sustainability, tourism and workforce, with the contention that the tourism industry holds, strengthens, continues and maintains, or sustains, precarity via its employment policies and practices (a thesis finding sympathy in Lee, Hampton \& Jeyacheya, 2015). By precarity, in a work context, we mean work which lacks security and predictability and which manifests as material and psycho-social depravation (cf. Alberti, Bessa, Hardy,Trappmann \& Umney, 2018).

Tourism contributes to employment for 275 million persons globally (WTTC, 2017), yet the academy has largely neglected the complexities and contributions of (working) people to tourism (Baum, Kralj, Robinson \& Solnet, 2016b). We demonstrate how tourism (historically and currently) sustains precarity vis-à-vis its employment practices. Precarity, an emerging sociological concept applied in the workforce context, speaks to the insecurities of work in capitalist economies. Precarity exposes implicit effects on the marginalisation and mobility, and exclusion and exploitation, of vulnerable populations (Alberti, Holgate \& Tapia, 2013). Our position is that tourism (employment) sustains deep social cleavages and economic inequalities thereby extending the precarious nature of work itself. We argue that not only is this unsustainable but, to disrupt this precarious cycle, the tourism academy and the tourism industry need to recalibrate the primacy of 'people', or the 'social' 
dimension of sustainability, in particular tourism workers, relative to the other dimensions of sustainability.

Ontologically, the all-pervasive neo-liberal paradigm that governs contemporary political, economic and social discourses, particularly in tourism, inhibits the ideals of sustainability (Gibson, 2009; Gössling, Ring, Dwyer, Andersson \& Hall, 2016; Tribe, Dann \& Jamal, 2015). As others have argued, capitalist and political agendas and applied business and managerial standpoints, drive tourism discourses without being recognised and challenged by conceptual, theoretical and empirical work in the field (Bianchi, 2017). This is no more so evident than in employment practices in tourism, which are generally characterised by such factors as low entry barriers, poor working conditions, loose regulation and mostly absent union representation (Baum, 2015). It is also worth reflecting, in our consideration of this theme, that a key mantra within the neo-liberal agenda is that of the flexible labour market (Arnold \& Bongiovi, 2013). Flexibility, in this context, is rarely reciprocal (Bolton \& Houlihan, 2007), with industry benefitting far more than workers in the long term, providing (as we will show)a fertile breeding ground for precarious work. Consequently, there is a pressing need to critically evaluate the values that underpin sustainability discourses in the context of employment. No other sector is as diverse as tourism especially with regards to its sub-sectors and its differences within local socio-politico-economic conditions. We embrace this diversity within this paper as do most of the data sources that we use. However, we also caution against an overgeneralisation of our findings across the entire sector and hence include contradictory interpretations of our arguments to remind the reader of the inherent complexities.

\section{Employment in tourism}

Tourism employment is diverse in the range of job types and skills it encompasses and is located across very different sub-sectors (such as travel facilitation, transport, accommodation, food services, attractions, heritage, events) at multiple levels within micro, medium and large organisations, both local and multinational. It is geographically dispersed and can be found in remote areas where a local skilled workforce is not readily available (Robinson, Ritchie, Kralj, Solnet, Baum \& Ford, 2014). It is also work that can be greatly influenced by the impacts of seasonality on precariousness, can be anti-social in the demands it makes on the working day and 
is frequently perceived to be of low status and limited desirability from a career perspective (Mooney, 2018). Tourism employees are highly mobile (Duncan, Scott \& Baum, 2013), frequently in the form of the exploitative employment of migrant labour (Janta, Ladkin, Brown \& Lugosi, 2011). Finally, tourism is at the forefront of the emergent collaborative or gig economy, within which the long-term employment consequences are unclear (Dredge \& Gyimóthy, 2015; Bertoli, Fernández-Huertas Moraga \& Keita, 2017). Therefore, it is difficult to generalise about work and the workforce in tourism. Writing some 20 years ago, eerily echoing much earlier Orwellian themes (1933), Wood (1997, p.198), provided a challenging perspective on work in one of tourism's largest sub-sectors, hospitality, when he declared that "hospitality work is largely exploitative, degrading, poorly paid, unpleasant, insecure and taken as a last resort or because it can be tolerated in the light of wider social and economic commitments and constraints".

As such, the fundamental characteristics of tourism employment do not seem to have reformed with the passage of time (Baum, 2015; 2018a). Employment in tourism continues to be associated with a lack of respect, esteem and standing relative to employment in other sectors, and poor remuneration is a perennial complaint (cf. De Beer, Rogerson \& Rogerson, 2014). The industry is largely hostile towards the endeavours of the trade union movement (Bergene, Boluk \& Buckley, 2015) and workplace contexts remain persistently obstinate regarding the expectations of legislation and broader industrial and community ethical requirements and expectations respectively (Poulston, 2008; The Guardian, 2018). Tourism work is almost synonymously associated with "low skills" (Ladkin, 2011) although it is acknowledged that this is partially a western-centric perspective (Nickson, Warhurst, Cullen \& Watt, 2003). In its broadest interpretation, tourism work can include engagement with exploitative employment, bordering on modern slavery that includes child labour, child sex work, child trafficking but also the exploitation of vulnerable adults through forced labour (Armstrong, 2016). Robinson (2013, p.94) highlighted modern slavery, in this context, as a "profound violation of human rights".

However, there is also recognition of a lack of clarity with respect to interpretations of job quality in the sector (Knox, Warhurst, Nickson \& Dutton, 2015; Knox, 2016). Where for a critical and agenda-driven outside observer the descriptor of 'bad job' may be apt, from the perspective of the job custodian it may represent an entirely different set of propositions. Perceptions of the quality of tourism jobs is 
contingent on the macro-context (economic and socio-cultural) in terms of, for example, gender and ethnicity (Adler \& Adler, 2004; McDowell, Batnitzky \& Dyer, 2009) as well as that of the attitude and aspirations of the individual in assessing the relative job opportunities available within the sector and the wider economy (Gursoy, Chi \& Karadag, 2013). It is also clear that there are many examples of tourism companies that commit to broad-based corporate social responsibility (CSR) and exhibit the highest standards in terms of ethical employment, offering work and careers on par with some of the best employers worldwide (Hughes \& Scheyvens, 2016).

Complex value chains that support the 'front-line' businesses are part of the tourism sector and provide additional challenges in terms of responsibility for working conditions and employment (Becker et al, 2010). As Methven, O'Brien and Dhanarajan (2016, p.551) note, "companies' failures to remediate more general supply chain responsibility issues probably remain the biggest problem of all" and, in tourism, these links extend across a wide range of sectors, both local and international. Consideration of employment in the industry is further complicated because of the fast-changing nature of the business structures that are evident in the form of partnerships, alliances, franchising and off-shored ownership models coupled with multi-employer sites, outsourcing, temporary forms of employment and selfemployment. Compared to other sectors of the economy, tourism operates within two parallel and largely interdependent worlds in organisational terms. These worlds represent, on the one hand, businesses within the formal, recognised and often registered (with tourism authorities) industry alongside, on the other, a grey or informal and unregulated tourism economy which can include a significant proportion of the total sector in many countries (McDonald, 1994; Jones, Ram \& Edwards, 2004; Bertoli et al., 2017). This is frequently in the form of self-employment or familybased work. Furthermore, with the emergence of a growing collaborative, platform or gig economy in tourism onto the international stage, the distinction between the formal and the informal is becoming increasingly blurred and, arguably, problematic from an employment perspective (Bertoli et al., 2017). These conditions only heighten the precarious nature of much tourism employment.

\section{Precarity, precarious work and the 'precariat'}


Precariousness, or precarity, in the broadest sense relates to a state defined by a lack of security and predictability, which when applied to the human condition manifests as material and psycho-social depravation (Alberti et al., 2018). Returning to our neo-liberal capitalist precepts (Bianchi, 2007; 2017; Gibson, 2009; Tribe et al., 2015), social scientists almost exclusively associate precarity with un/under and/or unstable employment (Wacquant, 2014). Standing's (2011) evocation of the Marxian proletariat (working class) in his portmanteau designation, 'the precariat', underscores the immutable entanglement of social and economic precarity with degrees of participation in the workforce. Precarious work is characterised by employment that is irregular and insecure; part-time/casual, quasi-self-employment, project or fixed-term work, temporary work (often via agencies), work on commission, on-call work, and increasingly a rise in home-based employment, and so-called 'telecommuting'. Some have even suggested that unpaid training and development and volunteering have somehow been ascribed as 'work' furthering the link between precarity and (un)employment (Smith, 2010). Vallas and Prener (2012, p. 332) observe that these non-standard forms of employment, work that lacks continuation over time and pay as well as social protection, have become increasingly prevalent since "large corporations have moved to dismantle the centralized or Fordist bureaucratic models on which they once relied". While labour history and industrial relations have always been prone to change, the past three decades have seen an acceleration of deregulation and privatisation (Ross, 2009) resultant in downsizing, even outsourcing, of labour within organisations changing standard working arrangement to increasing temporary, contract, and part-time arrangements, often against the volition of employees. The effects of insecure and unstable employment, or precarious work, include a higher exposure to declining health (mental as well as physical), increased financial instability, and widening societal gaps (Quan, 2017), thus creating precarious lives.

However, other narratives have developed framing the emergence of nonstandard work as a positive evolution for organisations and workers alike. The numerical and functional flexibility (Timo, 1999) afforded to employers, and the ability to reduce their payroll at a moments' notice contributes to nimble firms not constrained by the permanency of a standing workforce. Moreover, contingent workers rarely receive the entitlements of their permanent counterparts; leave and sickness benefits, superannuation, insurances and the like (Ross, 2009) thus further 
reducing payroll responsibilities to the benefit of organisations. From a worker's perspective, commentators have hinted at the emancipatory qualities of the new work order for employees to express 'free agency' (Vallas \& Prener, 2012) despite lessening financial stability. Among these are breaking the shackles of despotic and irrational workplace routines, with the introduction of flexible and project-based work, being able to take personal control and to charge fees commensurate with skills (Barley \& Munda, 2006). Bearing the 'creative class' trademark (Florida, 2014), the concept of the creative city has been born as a vision for the future, whereby workers in the knowledge economy thrive in fluid, highly connected, digitalised and vibrant, entrepreneurial and tech-edgy spaces that define the fourth industrial revolution (World Economic Forum, 2016). However, this also represents exclusion for those whose skills do not match the demands of the creative economy (Baum, 2018b).

Yet critiques of casual, or contingent, work have also been commiseratory. The espoused benefits of contingent work, and that of the creative class, have applied to highly remunerated and skilled professionals and managers of one description or another (Vallas \& Prener, 2012). Indeed, Gill and Pratt (2008, p. 3) consider creative workers to be "the poster boys and girls of the new 'precariat' ". Freelancers, consultants, entrepreneurs and start-up owners almost exclusively apply to those that work with their 'heads rather than their hands' - members of the knowledge economy (cf. Barley \& Kunda, 2006; Osnowitz, 2010). Manual jobs that provided stable and secure employment for a developed world middle-working class have disappeared due to a combination of automation and outsourcing, suggesting a polarisation of the workforce (Kalleberg, 2011).

Returning to the creative class, and illustrating this labour market dualism, Baum (2018b) has highlighted how an under-class of service workers, who are largely concealed and neglected in the 'creative cities' discourse, largely provision for the needs of those employed in the knowledge economy. Many provide services in the 'gig economy' (Horney, 2016) - rides with Uber, the raft of home delivery services for takeaway food and groceries, house cleaning, gardening services and so on. Ironically, many of these platforms disrupt poorly paid and unstable occupations, such as restaurant, transport and cleaning work, which incidentally are key services in tourism destinations. Baum (2018b) also posits that the inherently precarious nature of much creative (knowledge) work places many 'creatives' in direct labour market competition with 'traditional' service workers and that, for 
aesthetic rather than technical reasons, they are likely to displace them in many jobs. The rise of exploitative, unpaid internships within the creative sector is another example of precarious working (Siebert \& Wilson, 2013).

Other transient and mobile workers also compete for the service work in the new economy. As Anderson (2010, p.300) asserts, "migrants are often portrayed as working in sectors such as hospitality, construction, sex, agriculture and private households at the sharp end of de-regulated labour markets in jobs characterised by low wages, insecurity and obfuscated employment relations". Migrants, asylum seekers and refugees are particularly vulnerable to not only precarious work, but also to various forms of harassment and discrimination (McDowell et al., 2009). Two other specific labour markets are marked out by their transience and mobility, even if this is defined by temporality as much as it is by space and place. Women's and youth workforce participation has been steadily increasing for decades, yet each cohort has encountered issues of equality and wage parity. This is notwithstanding the willingness to engage in mobile and temporary labour, given the affordances of geographic mobility, for backpackers for instance (Cohen, 2011). Indeed, youth "acknowledge insecurity as a condition of youthful working life" (Morgan, Wood \& Nelligan, 2013, p. 410). Research consistently shows the intersectionality of migrants, women, ethnicity, race, youth, class and other marginal social groups (cf. Alberti, 2016; Alberti et al., 2013; Browne \& Misra, 2003; McDowell et al., 2009; Morgan et al., 2013). This is often a potent combination that culminates in two vulnerable, insecure, untenable and often inescapable conditions; precarious work and precarious lives.

\section{Precariousness, sustainability and the social dimension and work}

Precarious work and lives fall right within the ambit of social sustainability as they concern the people working within the tourism industry. Considering the emergence of sustainable tourism several decades ago following the seminal work of the Brundtland Report (1987) precariousness should technically be addressed and eliminated as part of the three sphere model. However, Boström (2012) highlights the neglect of the social pillar by policy makers and, indeed, researchers - the social dimension garners less attention or is dismissed altogether (Cuthill, 2010; Dillard, Dujon \& King, 2008Similarly, within the tourism domain, several authors have pointed out the neglect of the social sustainability sphere (Coles, Fenclova, \& Dinan, 
2013; Ruhanen, Weiler, Moyle \& McLennan, 2015) alongside that of bio-physical aspects (Vallance, Perkins \& Dixon, 2011).

The social, or people, domain is still poorly defined relative to its environmental and economic cousins (Dillard et al. 2008). ), yet elements such as community, education, health, housing, human rights and liveability are generally included within this domain. Equity, inclusivity, equality, diversity, representation and wellbeing, among others, are issues frequently lobbied for in the context of workplace, industrial relations and human resource development (Garavan, Heraty \& Morley, 1998). All elements that are in stark contrast to the concepts of precarity, precarious work and precarious lives. Baum (2018a) highlights the neglect of employment considerations in discussion, even in contemporary accounts of sustainable tourism (cf. Miller, Rathouse, Scarles, Holmes, \& Tribe, 2010). He notes the absence of employment or workforce-related themes within the dominant sustainability narrative. This is somewhat surprising considering sustainability agendas are invariably carried out by the tourism workforce, whether of a strategic nature in the design of policy, administrative or operational procedures, or indeed actually delivering them, for example effective recycling or reducing towel and sheet wash loads. No doubt, the design of organisational training and development programs prepare employees for their roles as agents of sustainable practices.

Yet sustainability, as a concept, has pervaded the employment literature, even if tourism has yet to take note of this development. Sustainable human resource management (SHRM) relates to practices that contribute to the development of human and social capital within the organisation. "Sustainable HRM represents a new approach to managing people, by identifying broader purposes for HRM, through its recognition of the complexities of workplace dynamics and the explicit recognition of the need to avoid negative impacts of HRM practices" (Kramar, 2014 , p.1085). As with the sustainability concept overall, the concept of sustainable human resource management has seen several offshoots (Ehnert, Harry \& Zink, 2013), such as socially responsible HRM, which is closely linked CSR. CSR is arguably a philanthropic and voluntary function, often designed to enhance market perceptions of an organisation (Coles et al., 2013) and so its sustainability priorities are less directed at the wellbeing of employees as such, but rather on economic sustainability. 
However, as Longoni and Cagliano (2015, p.218) assert, "social sustainability refers to actively supporting the preservation and creation of skills as well as the capabilities of future generations, promoting health and supporting equal and democratic treatments that allow for good quality of life both inside and outside of the company context". In this sense, there is a broader vision for sustainability extending beyond the workplace with the potential to address precariousness across all domains. Indeed, while Sustainable Development Goal no. 8 (UN, 2015), which calls for the promotion of 'sustained, inclusive and sustainable economic growth, full and productive employment and decent work', acts as a starting point for our work, a more lateral and nuanced approach to interpreting the SDGs via a workforce lens suggests the social, or people, dimension of sustainability, is spoken to by several of the SDGs (Baum et al., 2016a).

The remainder of this paper will critically examine a sample of contemporary reports and documents, which directly or indirectly speak to the precarious work and precarious lives of those employed in tourism and its allied industry sectors; hospitality, events, services and leisure. In so doing we aim to challenge current notions of sustainability more broadly, but particularly as applied to tourism, which we have already demonstrated in academic and policy endeavours marginalises both the sustainability social, or people, dimension - and its workforce.

\section{Data and methods}

To investigate the proposition that the tourism industry sustains precarity in its employment policies and practices, we sought to identify suitable industry literature within which we could conduct a critical content analysis. Precarity is conceptualised here as lack of security and predictability resulting in some form of depravation. Applying this concept to the realities of the (neo-liberal) tourism industry as outlined here, but also in other work (cf. Ladkin, 2011) a range of sensitising constructs (King, 2004 ) emerge. These constructs (as identified in Table 1) range from demographics (i.e. women or youth as marginalised groups in tourism work), to individual worker attributes (i.e. the increasing mobility of tourism employing frequently resulting in exploitative migrant labour) to industry characteristics (i.e. low wages, low skills, black/grey economy). To allow the analysis of the sustainability dimension of our 
argument below, the constructs are mapped against the SDGs in the left column, providing a basis for our industry data review below. 
Table 1: Key sensitising constructs

\begin{tabular}{|c|c|c|c|}
\hline \multirow{2}{*}{ SDG } & \multicolumn{3}{|c|}{ Constructs } \\
\hline & Demographics & Individual attributes & Industry characteristics \\
\hline $\begin{array}{l}\text { Goal 1: To end poverty in } \\
\text { all its forms and } \\
\text { everywhere. }\end{array}$ & \multirow{4}{*}{$\begin{array}{ll}- & \text { Gender } \\
- & \text { Age } \\
- & \text { Level of education } \\
- & \text { Race/ religion/ } \\
\text { ethnicity } \\
\text { - } & \text { Sexuality } \\
- & \text { Class }\end{array}$} & - Accommodation/housing status & $\begin{array}{ll}- & \text { Wages } \\
\text { - } & \text { Benefits (i.e. leave, medical benefits, } \\
\text { retirement funds/super) } \\
\text { - } & \text { Grey / informal economy } \\
\text { - } & \text { Black economy (slavery, sex tourism, } \\
& \text { trafficking) }\end{array}$ \\
\hline $\begin{array}{l}\text { Goal 3: To ensure } \\
\text { healthy lives and well- } \\
\text { being for all at all ages. }\end{array}$ & & $\begin{array}{ll}\text { - } & \text { Flexibility in regards to carer obligations } \\
\text { - } & \text { Flexibility overall } \\
\text { - } & \text { Substance abuse } \\
\text { - } & \text { Mental health } \\
\text { - } & \text { Accommodation/housing status }\end{array}$ & $\begin{array}{ll}- & \text { Hours of work } \\
- & \text { Working conditions } \\
\text { - } & \text { Benefits (i.e. leave, medical benefits, } \\
\text { retirement funds/super) } \\
\text { - } \quad \text { Black economy (slavery, sex tourism, } \\
\text { trafficking) }\end{array}$ \\
\hline $\begin{array}{l}\text { Goal 4: To ensure } \\
\text { inclusive and equitable } \\
\text { quality education and } \\
\text { promote lifelong learning } \\
\text { opportunities for all. }\end{array}$ & & $\begin{array}{ll}- & \text { Flexibility in regards to carer obligations } \\
\text { - } & \text { Flexibility overall }\end{array}$ & $\begin{array}{ll}- & \text { Level of skills } \\
\text { - } & \text { Promotional opportunities / career } \\
\text { progression / career pathways } \\
\text { - } \quad \text { Grey / informal economy }\end{array}$ \\
\hline $\begin{array}{l}\text { Goal 5: To achieve } \\
\text { gender equality and } \\
\text { empower all women and } \\
\text { girls. }\end{array}$ & & $\begin{array}{ll}\text { - } & \text { Flexibility in regards to carer obligations } \\
\text { - } & \text { Flexibility overall } \\
\text { - } & \text { Parental status }\end{array}$ & $\begin{array}{ll}\text { - } & \text { Wages } \\
\text { Benefits (i.e. leave, medical benefits, } & \text { retirement funds/super) } \\
\text { - } & \text { Promotional opportunities / career } \\
& \text { progression / career pathways } \\
\text { - } & \text { Grey / informal economy } \\
\text { - } & \text { Black economy (slavery, sex tourism, } \\
\text { trafficking) }\end{array}$ \\
\hline
\end{tabular}




\begin{tabular}{|c|c|c|}
\hline $\begin{array}{l}\text { Goal 8: To promote } \\
\text { sustained, inclusive and } \\
\text { sustainable economic } \\
\text { growth, full and } \\
\text { productive employment } \\
\text { and decent work. }\end{array}$ & $\begin{array}{ll}\text { - } & \text { Flexibility in regards to carer obligations } \\
\text { - } & \text { Flexibility overall } \\
\text { - } & \text { Tenure/mobility }\end{array}$ & $\begin{array}{ll}- & \text { Wages } \\
\text { - } & \text { Hours of work } \\
\text { - } & \text { Working conditions } \\
\text { - } & \text { Benefits (i.e. leave, medical benefits, } \\
& \text { retirement funds/super) } \\
\text { - } & \text { Grey / informal economy } \\
\text { - } & \text { Black economy (slavery, sex tourism, } \\
& \text { trafficking) }\end{array}$ \\
\hline $\begin{array}{l}\text { Goal 10: To reduce } \\
\text { inequality within and } \\
\text { among countries. }\end{array}$ & - Mental health & $\begin{array}{ll}- & \text { Mobility / portability of skills } \\
\text { - } & \text { Black economy (slavery, sex tourism, } \\
\text { trafficking) }\end{array}$ \\
\hline $\begin{array}{l}\text { Goal 16: To promote } \\
\text { peaceful and inclusive } \\
\text { societies for sustainable } \\
\text { development, provide } \\
\text { access to justice for all } \\
\text { and build effective, } \\
\text { accountable and } \\
\text { inclusive institutions at } \\
\text { all levels. }\end{array}$ & $\begin{array}{ll}\text { - } & \text { Substance abuse } \\
\text { - } & \text { Mental health }\end{array}$ & $\begin{array}{ll}\text { - } & \text { Mobility / portability of skills } \\
\text { Black economy (slavery, sex tourism, } \\
\text { trafficking) }\end{array}$ \\
\hline
\end{tabular}


Industry data search and analysis

To explore our contention that the precarious nature of tourism employment is at odds with sustainability, we sought secondary industry data to investigate whether tourism employment represents precariousness. The industry data was identified and analysed in a two-step process, which was informed by the methodologies of similar document analyses (Homeshaw, 1995; Solnet, Nickson, Robinson, Kralj \& Baum, 2014). Initially, a purposive tiered sample of industry reports and data was sought according to the following selection criteria:

a. In sampling preference was given to the most comprehensive primary data reports, from reputable and recognisable organisations, although secondary data (reports that had already processed data to generate some argument, narrative or advocacy position) were included;

b. A quantitatively balanced sample for three tiers was established: global data, regional data and national data relating to the tourism and hospitality industry/sector. Several of the resources did not necessarily have sectorspecific data but rather contained economy-specific data (e.g., International Labour Organisation [ILO]). Where feasible this was cross-referenced with highly tourism dependent economies (e.g. the Maldives, where tourism comprises $28 \%$ of GDP and over $60 \%$ of their foreign exchange earnings). The assumption was that the ILO data for highly tourism dependent countries would more closely approximate industry conditions.

c. A qualitatively balanced data set reflecting the global labour market and workforce in tourism (e.g. developed and developing economies).

Our final sample included 14 reports. Table 2 outlines the reports by level of analysis (global, regional or national). We searched these documents for the constructs listed in Table 1. Some topics, for example wages and gender, were overrepresented and others, such as substance abuse and mental health, did not yield any results despite these appearing in tourism occupational literature (cf. Giousmpasoglou, Brown, \& Cooper, 2018; Kotera, Adhikari \& Van Gordon, 2018).

Table 2: Data sources per level of analysis

\begin{tabular}{|l|l|}
\hline Level & Reports \\
\hline Global data & $\begin{array}{l}\text { The World Tourism and Travel Council's Global talent trends and } \\
\text { issues for the travel and tourism sector (2015), }\end{array}$ \\
\hline
\end{tabular}




\begin{tabular}{|c|c|}
\hline & $\begin{array}{l}\text { - The World Bank's Worldbank Indicators data platform (2018), } \\
\text { - The ILO's Developments and challenges in the hospitality and tourism } \\
\text { sector (2010), } \\
\text { - The ILO's Key indicators of the labour market (2016) and } \\
\text { - ILOSTAT data (2018). }\end{array}$ \\
\hline Regional data & $\begin{array}{l}\text { - } \quad \text { OECD's Supporting Quality Jobs in Tourism (Stacey, 2015), } \\
\text { - The EU's Skills Panorama (2018) platform, } \\
\text { - } \quad \text { The EU's Eurostat: Tourism industries employment (2018) and } \\
\text { - } \\
\text { APEC's Developing the Tourism Workforce of the Future in the APEC } \\
\text { Region (2017). }\end{array}$ \\
\hline National data & $\begin{array}{l}\text { - Deloitte's Australian Tourism Labour Force Report: 2015-2020 (2015), } \\
\text { - Biehl and Kaske's report on Tourism in Austria (2011, where required } \\
\text { translated from German by one of the authors), } \\
\text { - Berg and Farbenlum's (2017) Wage theft in Australia, } \\
\text { - } \quad \text { ANZ's Servicing Australia's future (2016) and } \\
\text { - } \quad \text { Australia Parliament's Current vacancies: Workforce challenges facing } \\
\text { the Australian tourism sector (2007). }\end{array}$ \\
\hline
\end{tabular}

In analysing the reports using the constructs identified, two separate but linked themes were evident. Firstly, evidence of precarious employment within the tourism industry, including employment that lacks security or predictability, either temporarily, spatially or monetarily. Secondly, and as a result of the first theme, evidence emerged of how employment in tourism, and its allied sectors, contributes to precarious lives. Both themes form the basis of the analysis which follows.

\section{Precarious employment}

Focusing initially on working conditions, globally tourism workers consistently earn less than the all-industries average. In Canada tourism workers earn $47 \%$ of the average, in Chile, 91\%, New Zealand, 49\%, Philippines, 42\% and Indonesia 17\%. (APEC, 2017). Specifically, according to OECD reports, in hotels and restaurants earnings were about $37 \%$ lower than average earnings in the economy as a whole, and up to $60 \%$ lower in some countries (Stacey, 2015). Similarly, EuroSTAT (2015) reported that average hourly earnings were $€ 14.10$ in 2010 and average tourism hourly earnings amounted to $€ 12.10$, adding that for the same year accommodation sector gross hourly earnings were $€ 9.50$, evidence corroborated by the literature visà-vis hotel workers (Alberti, 2016). In a survey of APEC economies, (2017), foodservice roles were particularly poorly remunerated, and predominated as the lowest paid job regardless of nationality, across four of the six top countries (China, South Korea, Brazil and India). According to Biehl and Kaske (2011), the median 
monthly income in tourism in Austria was a third below the overall median, trailing only the home services and agriculture industries.

Evidence supported the expectation that tourism had a high share part-time, casual and seasonal employment profile (WTTC, 2015). Within the EU and other Western contexts, the United Kingdom (50\%) and the Netherlands (68\%) reported high rates of part-time tourism employment (ILO, 2010), in the Czech Republic and Sweden the proportion of part-time workers in tourism is almost twice as high as it is in the economy as a whole (EuroSTAT, 2015). In Australia $41 \%$ of tourism employees are employed part-time compared to all-industries average of $32.5 \%$ (Australian Parliament, 2007). In Spain only 64\% of the workforce is employed throughout the whole year - a consequence of the sun, sea and sand driven seasonality (ILO, 2010).

Subcontracting and outsourcing accounted for $4.6 \%$ of tourism employees in Spain. Moreover, tourism dominated marginal employment contracts, $18 \%$ compared with $8 \%$ in the overall economy (Biehl \& Kaske, 2011). Enterprise bargaining agreements have gradually been replacing award-based systems in Australia (Australian Parliament, 2007) whittling away penalty rates, traditionally geared at rewarding non-standard working hours (Knox, 2006). While the hospitality and tourism sector is characterised by high fragmentation, approximately $20 \%$ of the workforce is located within multinational corporations (MNC). MNCs have a high propensity for both casualised and outsourced labour (McDowell et al., 2009). Workers in (contingent) non-standard employment, highly prevalent in tourism (Baum, 2015), faced substantial wage penalties in the US and Europe, relative to comparable standard workers, reaching 30\% (ILO, 2016). Across the reports there was consistent evidence of longer hours than in other sectors (Berg \& Farbenblum, 2017).

Tourism is a significant employer of women globally (56\% females to $46 \%$ males) (The World Bank, 2018), and much higher in many economies, for example in Poland and Slovakia $67 \%$ are employed in tourism versus $36 \%$ in the economy as a whole (EuroSTAT, 2015). Tourism has been a driver of women's workforce participation, although assumptions regarding whether this is positive are being questioned (Duffy, Kline, Mowatt \& Chancellor, 2015). Regardless, in Australia women's participation in the tourism labour force increased from $51 \%$ in 1978 to $70 \%$ in 2016 (ANZ, 2016). Typically, women in developed nations comprise $50-60 \%$ of 
the workforce, while in developing countries the figure can be much higher, with Thailand (65\%), Vietnam (70\%) and Peru (76\%) being illustrative examples, although rates of self-employment in these nations are higher (APEC, 2017) - in itself a marker of precarity (Jones et al, 2004; Bertoli et al., 2017). Interestingly, however, the data consistently show women's earnings, across all jurisdictions, lagging behind that of men (Berg \& Farbenblum, 2017; Biehl \& Kaske, 2011; EuroSTAT, 2015), by an average of $25 \%$ less for comparable skills (ILO, 2010), according to accounts of gender precarity in tourism and hospitality employment (Santero-Sanchez, Segovia-Pérez, Castro-Nuñez, Figueroa-Domecq \& TalónBallestero, 2015).

Tourism is an important employer of youth (WTTC, 2015). For example, in Spain 43\% of workers in the sector are aged 25-34 (ILO, 2010), in Denmark, Malta and the Netherlands the figure exceeds 20\% (EuroSTAT, 2015). Across European OECD countries $47 \%$ of the 15-34 years cohort are employed in tourism, compared to $32.4 \%$ in the economy as a whole (Stacey, 2015). This compares to $26 \%$ in Australia (Australian Parliament, 2007). The US Bureau of Statistics reports that in food preparation and service roles there are more workers aged between 16 and 20 than those aged 20 and over (ILO, 2010). The prevalence of youth in the workforce perhaps speaks to the low skilled occupations that comprise its sectors.

Yet still, skill gaps persist especially in developed countries (ILOSTAT, 2018; WTTC, 2015). A majorative $69 \%$ of Australian businesses identified skills deficiencies in their tourism workforce (APEC, 2017), yet the industry is notorious for being training avoiders (Lashley, 2009). Our data show that few companies in most economies seriously consider skills investment, Iceland being an anomaly (Stacey, 2015). However, when marginal groups are considered the picture changes complexion. High proportions of skilled and educated women and migrants are under-employed, relevant to their qualifications (Biehl \& Kaske, 2011), and given that worldwide educational levels of the labour force are improving, there is evidence that un/under employment is a higher risk to the educated than the uneducated migrant (ILO, 2016) further making vulnerable populations susceptible to exploitative conditions (Browne \& Misra, 2003; McDowell, et al., 2009). Our study shows that tourism is decreasingly becoming a 'catch all' for those with lower levels of education (EuroSTAT, 2015; Stacey, 2015) although the reasons are contextual and varied. 
Nonetheless, from EuroSTAT (2015) data 30 from 40 regions with the highest tourism intensity have an unemployment rate below the national average.

Regardless, tourism and mobility are synonymous, affording benefits to those who are prepared to move for employment. However, the data show that workers in tourism demonstrated a higher proclivity for seeking exit strategies from their work. The Biehl and Kaske (2011) report found that a third of tourism workers wanted to leave their organisation or sector, compared to $16 \%$ of those in other sectors. The OECD reports that $45 \%$ of tourism employees stayed in the same job for less than two years, as compared to the $25 \%$ all-industries average (Stacey, 2015) with EuroSTAT (2015) reporting similar statistics. Australian data show that employees, especially in regional areas, consider tourism employment as only short-term (Deloitte Access Economics, 2015).

Mobility into tourism is eased by low entry barriers (WTTC, 2015). Biehl and Kaske (2011) report that seasonality is the catalyst for much mobility, with only $54 \%$ of tourism workers employed year-round. Moreover, $71 \%$ of workers took extended breaks out of tourism, with women far more likely to interrupt than men. Interestingly, economies with higher rates of temporary employment were more likely to see workers transiting between contingent labour and unemployment. The likelihood of transitioning to better jobs was less probable (ILO, 2016).

In relation to mobility, the industry is more likely to attract foreign workers compared to the economy average precipitating high rates of cross-border migration (WTTC, 2015), as evident in much recent literature (cf. Janta et al., 2011; McDowell, 2009; Robinson et al., 2014). In Biehl and Kaske's (2011) Austrian report social security data reveals that $36 \%$ of the tourism workforce (compared with $13.8 \%$ in the whole economy) have foreign citizenship. Foreign workers comprise $8 \%$ of the air transport sector, in travel agencies and/or tour operators, yet $17 \%$ of the accommodation labour market (EuroSTAT, 2015). Unsurprisingly, international students, working holiday makers and temporary migrants all intersect with the lowest wages (Berg \& Farbenblum, 2017). These populations are vulnerable to the grey and black economies (ILO, 2010) as noted in the literature (Armstrong, 2016 ). Berg and Farbenblum (2017), in the Australian context, reveal that unauthorised workers on tourist visas and temporary migrants work for well-below award wages, and are often paid in cash with no payment record. Their recourse to challenge their working conditions is seriously comprised, as is their ability to live stable and 
dignified lives beyond work. We now turn to themes in the data that speak to precarious lives.

\section{Precarious lives}

The Biehl and Kaske (2011) data from an Austrian survey found that $46 \%$ of respondents stated that their wage is just enough to make ends meet, and $15 \%$ reported that it was not sufficient. In addition, $25 \%$ of the Austrian respondents suspected that their wages would not be enough to earn them a pension on which they would be able to live (Biehl \& Kaske, 2011). In Australia, a steady decline in real wages contributed to rising income inequality such that household spending dropped and concurrently income to buy capital assets, such as housing, reduced further (ANZ, 2016). A report on employees of Disneyworld (although caution must be exercised in the interpretation of its findings) revealed that $56 \%$ of workers responding to their survey reported concerns regarding eviction, that one in 10 had been homeless in the past two years, and that over half resided in overcrowded accommodation (Dreier \& Flaming, 2018), a clear illustration of the working poor, the precariat, in tourism.

While our earlier discussion focused on wage inequality, in the Maldives, on average $2 \%$ of all employed females' earnings left them below the poverty line, compared to about $1.7 \%$ of males (ILOSTAT, 2018; see also Horemans, Marx \& Nolan, 2016). Cultural and structural reasons, for instance the aforementioned Maldivian Muslim observances (Jafari \& Scott, 2014) and child-caring responsibilities (Browne \& Misra, 2003) respectively, underpin why women make up less than $40 \%$ of total wage employment, yet represent $57 \%$ of part-time employees. Many women work part-time as it allows them to combine paid work with domestic and care responsibilities (ILO, 2016). Similarly, either formal labour market exclusion, or flexibility to fulfil carer duties (McMillan, O'Gorman \& MacLaren, 2011), conspire to make self-employment attractive. OECD data reports that $24 \%$ of women seek selfemployment in tourism compared to $19 \%$ in the overall economy (Stacey, 2015). Similarly, contingent workers in the gig economy, in data obtained from Uber, Airbnb and a report on Crowdworkers indicates that it is not millennials who dominate the sector, but rather workers in their notional 'prime' (25-55 years old) (APEC, 2017). Women, in particular seem to show more willingness to 'dip their toes in the water' of traditional male-dominated industries, via the gig economy (APEC, 2017). The 
immense flexibility, demands and precarity characterising the gig economy (Baum, 2018b) can be a mixed blessing. In some economies, for example Singapore and the Philippines, Uber is promoted as a life-style choice, allowing flexibility in choices in some economies (Lim, 2017; Moragra, 2017) yet the low rates of pay, and pressure to 'put food on the table' may be incompatible with the parenthood duties that invariably fall on middle-aged women, in developed and developing economies alike.

On a more sombre note, predominantly in developing countries, it is estimated that two million children are commercially and sexually exploited (ILO, 2010), with Robinson (2013) arguing that the sex, tourism and hospitality industries are inherently intertwined. By any definition these children are being deprived their childhood and dignity (Black, 1995). Needless to say, that these workers in the grey and/or black economies are excluded from their employment benefits, but the evidence is that so too are many non-standard, or contingent workers in tourism (ILO, 2016). These contingent tourism worker entitlements, which include inter alia sick leave, medical care, recreation leave and retirement funds lag behind allindustry comparisons (APEC, 2017), and are significant in that they impact quality of life beyond the workplace, spatially and temporally.

Triangulating the evidence from our study there is also evidence of the intersectionality of some aspects of precarity beyond that of the commonly presented socio-economic: that is the intersection of the demographics and characteristics of workers, for example gender, age, race, class and migrant or refugee status (e.g., Alberti, 2016; Browne \& Misra, 2003; Morgan et al., 2013). We have found evidence of precariousness at work, compounding the insecurity of work itself and the precariousness of life. This triumvirate of precarity constitutes the existing doublejeopardy of precarious work and precarious lives, and further marks out Standing's (2011) notion of the precariat.

\section{Sustaining precarious tourism employment}

Summarising key findings relative to sustainability, precarious work and precarious lives several key themes emerge that connect these topics. Intersectionality (Alberti, 2016), mobility (Duncan et al., 2013), exploitation (Robinson, 2013; Siebert \& Wilson, 2013; Wood, 1997), a paradox of low skills required (Baum, 2015) but rising education levels (Stacey, 2015), contributions to poverty in work (Dreier \& Flaming, 2018; Horemans et al., 2016) and the neo-liberal-driven polarisation of the workforce 
(Kalleberg, 2011) come to the fore. Granted, these are nuanced between different jurisdictions, developed and developing economies, and prevailing socio-politicoeconomic conditions (Baum, 2018a).

Table 3 maps evidence from our analysis and discussion to the SDG's. This summary presents a bleak assessment of the UN's SDGs and suggests that in many contexts, the precarious nature of much tourism work makes a counter-contribution to the achievement of key SDGs despite being often celebrated as a key job driver within the SDGs (UN, 2015).

\section{Table 3: Sustainable Development Goals and Tourism Employment}

\begin{tabular}{|c|c|}
\hline SDG & Implications of precarious employment in tourism \\
\hline $\begin{array}{l}\text { Goal 1: To end poverty in } \\
\text { all its forms and } \\
\text { everywhere. }\end{array}$ & $\begin{array}{l}\text { We have seen the extent to which part-time, seasonal and other forms of } \\
\text { precarious work feature in tourism. Such work can frequently perpetuate in- } \\
\text { work poverty, creating the working poor }\end{array}$ \\
\hline $\begin{array}{l}\text { Goal 3: To ensure healthy } \\
\text { lives and well-being for all } \\
\text { at all ages. }\end{array}$ & $\begin{array}{l}\text { The nature of much tourism work runs counter to work-life balance objectives } \\
\text { and runs counter to this goal in relation to workers, their families and their } \\
\text { communities. }\end{array}$ \\
\hline $\begin{array}{l}\text { Goal 4: To ensure } \\
\text { inclusive and equitable } \\
\text { quality education and } \\
\text { promote lifelong learning } \\
\text { opportunities for all. }\end{array}$ & $\begin{array}{l}\text { Those in precarious work are disproportionately disadvantaged in terms of } \\
\text { accessing education and opportunities for lifelong learning, compounded by a } \\
\text { sector, tourism, where investment in training and development is significantly } \\
\text { lower than economy averages in most countries. }\end{array}$ \\
\hline $\begin{array}{l}\text { Goal 5: To achieve gender } \\
\text { equality and empower all } \\
\text { women and girls. }\end{array}$ & $\begin{array}{l}\text { Women are over-represented in the global tourism industry, especially in } \\
\text { terms of self-employment within the informal economy but they are markedly } \\
\text { under-represented in positions of authority and leadership. Tourism, therefore, } \\
\text { contributes little to gender equality }\end{array}$ \\
\hline $\begin{array}{l}\text { Goal 8: To promote } \\
\text { sustained, inclusive and } \\
\text { sustainable economic } \\
\text { growth, full and productive } \\
\text { employment and decent } \\
\text { work. }\end{array}$ & $\begin{array}{l}\text { Tourism, as noted in this paper, faces systemic and structural challenges with } \\
\text { respect to the delivery of decent work opportunities and perpetuates } \\
\text { exploitative work that, at times, merges with modern slavery. }\end{array}$ \\
\hline $\begin{array}{l}\text { Goal 10: To reduce } \\
\text { inequality within and } \\
\text { among countries. }\end{array}$ & $\begin{array}{l}\text { The precarious nature of tourism work leaves many employees in a marginal } \\
\text { relationship with the wider society in which they live, unable to participate fully } \\
\text { in economic, social or cultural terms. Tourism work, by and large, does not } \\
\text { provide opportunities for social mobility or the reduction in inequalities in most } \\
\text { countries }\end{array}$ \\
\hline $\begin{array}{l}\text { Goal 16: To promote } \\
\text { peaceful and inclusive }\end{array}$ & $\begin{array}{l}\text { Peace and inclusivity require communities in harmony with themselves, based } \\
\text { in an equitable distribution of opportunity for key stakeholders (for example }\end{array}$ \\
\hline
\end{tabular}




\begin{tabular}{|l|l|}
\hline $\begin{array}{l}\text { Societies for sustainable } \\
\text { development, provide } \\
\text { access to justice for all }\end{array}$ & $\begin{array}{l}\text { youth and women) and fair access to collective wealth. The nature of much } \\
\text { precarious tourism work runs diametrically counter to this SDG. } \\
\text { and build effective, } \\
\text { accountable and inclusive } \\
\text { institutions at all levels. }\end{array}$ \\
\hline
\end{tabular}

Perhaps of most concern in this cross tabulation is that precarity, as a concept leading contemporary analyses of work relations, is borne out of reasonably recent post-Fordist industrial developments (Vallas \& Prener, 2012). However, the compelling evidence is that while other industries may have become a locus for precarious work, tourism always has had such attributes (Orwell, 1933; Wood, 1997). The marginal worker thesis in tourism and hospitality (Robinson, 2008; Wood, 1992) significantly predated this post-Fordist turn (Morgan et al., 2013). The effects of right wing populism, some are convinced (Cumming, Wood \& Zahra, 2016), will exacerbate the precarity of contingent workers via an erosive evolution of HRM practices and employment law. More than this, our analyses of global, regional and national data sources support the contention that contingent and non-standard employment increasingly attracts populations from the margins of society (Alberti et al., 2013; McDowell et al., 2009; Morgan et al., 2013), and so perpetuates, or sustains, their precarious lives.

\section{Conclusion and Future Research}

Our critical review in this paper presents a fundamental challenge to neo-liberal charged notions of tourism (Bianchi, 2009, 2017) and sustainable tourism (Gibson, 2009; Tribe et al., 2015) and the contribution which many writers believe tourism can make towards its attainment. By moving the conversation away from the dominant environmental - economic narrative in relation to sustainability and focusing on the social sustainability pillar, we have exposed significant flaws in the prevailing discourse about tourism existing in harmony with sustainable development goals. Our evidence points clearly to the (increasingly) precarious nature of much tourism employment and the manner in which this runs counter both to the objectives of sustainable HRM (Ehnert, 2009) and to the underpinning objectives of the UN's SDGs. Our findings also run counter to the ILO's (2012) aspirations for decent work in tourism (Baum, 2018a). As we have noted earlier, we do accept that notions of 
precarious work (and with it both the nature of job quality and the remedies available to improve it) are contested. Knox et al. (2015) point to inherent ambiguity with respect to interpretations of job quality in the sector while Knox (2014) further argues that, in the context of precarity, investment in employees working for agencies through enhanced training opportunities and higher levels of remuneration can pay dividends in terms of productivity and reduced turnover.

The conceptual contribution therefore, is to propose the need for a recalibration of sustainability in tourism relative to the social dimension, and specific to the workforce. The current discourse privileges the economic-environmental dimensions thus neglecting the social subsequently sustaining precarity via employment (Wacquant, 2014). Sustainable employment in tourism would offer opportunities for decent, rewarding, developmental work for all, without distinction on the basis of gender, ethnicity, age, disability or sexuality, work that allows employees to balance employment with family, social and leisure rights and obligations.

This aspiration also provides our route to the practice and policy implications of this narrative because stakeholders, whether governments, the tourism industry and the third sector must be charged with making this aspiration into a reality and that will require tripartite collaboration but also commitment from all parties to the business and ethical advantages of change (cf. Gössling et al., 2015). Ensuring decent work and dignity within tourism employment, likewise, should be enshrined in existing CSR policies - eliminating the precarity in casual work patterns is one key strand within this. Ultimately, flexible work need not be precarious work provided that organisations recognise all their employees, irrespective of their time or status commitment to the company, as valuable and contributing members of the team and that flexibility is recognised as a reciprocal practice.

As our paper demonstrates, the precarious nature of work in tourism has generated considerable rhetoric, even polemic in a general sense but also in a more focused way that relates to the UN's SDGs. The prima facie case that good working conditions (in the sense of sustainable HRM practices) generate positive outcomes for both employees and businesses seems to be difficult to refute - but much more challenging to demonstrate empirically. And yet, as we also argue, practices across many sectors of tourism are frequently far removed from being sustainable. There is a need for research that interrogates issues of employment precarity across all its dimensions and within the full spectrum of tourism sector contexts in both the formal 
and informal/ gig economies. A research agenda for the area has to be multimethodological in approach, recognising the value of studies that range from the ethnographic through to hard survey data. Indeed, aspirations for change in the tourism workplace would be greatly enhanced by the availability of more definitive trend data within major social, employment and economic statistics, where currently issues of sector definition within Standard Occupational Classification (SOC) systems hinder comparative clarity. There is also need for an evidence-base which locates the consequences of precarity in the tourism workplace in a wider socioeconomic context, scaling location-specific studies (cf. Drier \& Fleming, 2018) to the level of the destination or sub-sector within tourism.

Our broad-brush analysis in this paper begs as many questions as it answers, setting the platform for future research. At the broadest level are the underpinning neo-liberal foundations, on which tourism has seemingly grown incompatible with an authentic sustainability vision, as manifest by tourism employment sustaining precarity? These data we address are, generally, high level and require careful drilling down on the basis of geographical location, sector variation and how intersectionality presents itself beyond the headlines. In this study, we were unable to engage with data in this way. In building the case for sustainability in tourism employment, there is also a need to drill much deeper into the polemics and the rhetoric about the jobs people do (Vallas \& Prener, 2012) in the industry, as others are doing, for example in relation to migrants (McDowell et al., 2009) and intersectionality (Browne \& Misra, 2003). This will provide a far greater understanding of the ambivalent relationship between sustainable development, and the triumvirate of precarious tourism employment at work, precarious tourism employment of work - and precarious lives. 


\section{References}

Adler, P.A. \& Adler, P. (2004). Paradise laborers: Hotel work in the global economy. Ithaca: Cornell University Press.

Alberti, G., Bessa, I., Hardy, K., Trappmann, V., \& Umney, C. (2018). In, Against and Beyond Precarity: Work in Insecure Times. Work, Employment and Society, 32(3), 447-457.

Alberti, G., Holgate, J. \& Tapia, M. (2013). Organising migrants as workers or as migrant workers? Intersectionality, trade unions and precarious work, International Journal of Human Resources Management, 24(22), 41324148.

Anderson, B. (2010) Migration, immigration controls and the fashioning of precarious workers, Work, Employment and Society, 24(2), 300-317

ANZ Research In-Depth (2016). Servicing Australia's future. University of Queenland/AIBE. Retrieved from: https://aibe.uq.edu.au/files/224/Servicing Australias Future 2030 June 2016. pdf

Armstrong, R. (2016), "Modern slavery: risks for the UK hospitality industry", in Goodwin, H. and Font, X. (Eds), Progress in Responsible Tourism V, Goodfellow Publishers, Oxford, pp. 67-78..

Arnold, D. \& Bongiovi, J. (2013). Precarious, informalizing, and flexible work. transforming concepts and understandings, American Behavioral Scientist, 57(3), 289-308.

Asia-Pacific Economic Cooperation (APEC) (2017). Developing the Tourism Workforce of the Future in the APEC Region. Retrieved from: https://www.apec.org/Publications/2017/04/Developing-the-Tourism-Workforceof-the-Future-in-the-APEC-Region

Australia Parliament House of Representatives. Standing Committee on Employment, Workplace Relations and Workforce Participation (2007).

Current vacancies: Workforce challenges facing the Australian tourism sector. Canberra: Commonwealth of Australia. Retrieved from: https://trove.nla.gov.au/work/5531434?selectedversion=NBD41895629

Barley, S.R. \& Kunda, G. (2006). Contracting: A new form of professional practice. The Academy of Management Perspectives, 20(1), 45-66. 
Baum, T. (2018a). Sustainable human resource management as a driver in tourism policy and planning: A serious sin of omission? Journal of Sustainable Tourism https://doi.org/10.1080/09669582.2017.1423318

Baum, T. (2018b) Changing employment dynamics within the creative city: Exploring the role of 'ordinary people' within the changing city landscape, Economic and Industrial Democracy https://doi.org/10.1177/0143831X17748371

Baum, T. (2015). Human resources in tourism: Still waiting for change? A 2015 reprise. Tourism Management, 50, 204-212.

Baum, T., Cheung, C., Kong, H., Kralj, A., Mooney, S., Nguyễn Thị Thanh, N., Ramachandran, S., Ružić. M.D. \& Siow, M.L. (2016a). Sustainability and the tourism and hospitality workforce: A thematic analysis. Sustainability, 8(8), 809.

Baum, T., Kralj, A., Robinson, R.N.S. \& Solnet, D. J. (2016b). Tourism workforce research: A review, taxonomy and agenda. Annals of Tourism Research, 60, 122.

Becker, W. S., Carbo, J. A., and Langella, I. M. (2010). Beyond self-interest: Integrating social responsibility and supply chain management with human resource development, Human Resource Development Review, 9, 144-168

Berg. L. \& Farbenblum, B. (2017). Wage theft in Australia. Sydney: Migrant Worker Justice Initiative: UNSW/UTS. Retrieved from:

https://static1.squarespace.com/static/593f6d9fe4fcb5c458624206/t/5a11ff31ec 212df525ad231d/1511128887089/Wage+theft+in+Australia+Report final web. pdf

Bergene, A.C., Boluk, K. \& Buckley, E. (2015). Examining the opportunities and challenges of union organisation within the hospitality industry, in (Eds) Jordhus-Lier, D. and Underthun, A. A hospitable world? Organising work and workers in hotels and tourist resorts, London: Routledge: pp. 195-212.

Bertoli, S., Fernández-Huertas Moraga, J. \& Keita, S. (2017). The Elasticity of the Migrant Labour Supply: Evidence from Temporary Filipino Migrants. The Journal of Development Studies, 53(11), 1822-1834.

Bianchi, R. (2017). The Political Economy of tourism development: A critical review. Annals of Tourism Research. doi.org/10.1016/j.annals.2017.08.005

Bianchi, R. (2009). The 'critical turn'in tourism studies: A radical critique. Tourism Geographies, 11(4), 484-504.

Biehl, K. \& Kaske, R. (2011). Tourismus in Östereich (mit einer Sonderauswertung 
des Österreichischen Arbeitsklimaindex), Kammer für Arbeiter und Angestellte für Wien, Östereich.

Black, M. (1995). In the Twilight Zone: Child workers in the hotel, tourism, and catering industry, International Labour Organization: Geneva.

Bolton, S. \& Houlihan, M. (2007). Beginning the search for the H in HRM. In S. Bolton, \& M. Houlihan (Eds.), Searching for the human in human resource management: theory, practice and workplace contexts, Basingstoke: Palgrave: pp. 1-28.

Boström, M. (2012). A missing pillar? Challenges in theorizing and practicing social sustainability: introduction to the special issue, Sustainability: Science, Practice and Policy, 8(1), 3-14.

Browne, I. \& Misra, J. (2003). The Intersection of Gender and Race in the Labor Market. Annual Review of Sociology 29: 487-513.

Brundtland, G., et al. (1987). Our Common Future, (''brundtland reportl'). Retrieved from: http://www.citeulike.org/group/13799/article/13602458

Cohen, S.A. (2011). Lifestyle travellers: Backpacking as a way of life. Annals of Tourism Research, 38(4), 1535-1555.

Coles, T., Fenclova, E., \& Dinan, C. (2013). Tourism and corporate social responsibility: A critical review and research agenda. Tourism Management Perspectives, 6, 122-141.

Cumming, D., Wood, G. \& Zahra, S., (2016) The Rise of Right Wing Populism and Its Effect on HRM,: Retrieved from http://dx.doi.org/10.2139/ssrn.2879078

Cuthill, M. (2010) Strengthening the "social" in sustainable development: developing a conceptual framework for social sustainability in a rapid urban growth region in Australia. Sustainable Development 18(6), 362-373.

De Beer, A., Rogerson, C., and Rogerson, J. (2014). Decent work in the South African tourism industry: Evidence from tourist guides. Urban Forum, 25(1), 89103.

Deloitte Access Economics (2015). Australian Tourism Labour Force Report: 20152020. Canberra: Australian Trade Commission, Austrade. Retrieved from: https://www.tra.gov.au/ArticleDocuments/185/Australian Tourism Labour Forc e FINAL.PDF.aspx?Embed=Y

Dillard, J., Dujon, V. \& King, M.C. (Eds.). (2008). Understanding the Social Dimension of Sustainability. New York: Routledge. 
Dredge, D. \& Gyimóthy, S. (2015). The collaborative economy and tourism: Critical perspectives, questionable claims and silenced voices, Tourism Recreation Research, 40(3), 286-302.

Drier, P. \& Flaming, D. (2018). Working for the Mouse: A Survey of Disneyland Resort Employees. Occidental College Urban \& Environmental Policy Institute and the Economic Roundtable. Retrieved from: https://www.oxy.edu/urbanenvironmental-policy-institute

Duffy, L.N., Kline, C.S., Mowatt, R.A. \& Chancellor, H.C. (2015). Women in tourism: Shifting gender ideology in the DR. Annals of Tourism Research, 52, 72-86.

Duncan, T., Scott, D.G. \& Baum, T. (2013). The mobilities of hospitality work: An exploration of issues and debates. Annals of Tourism Research, 41, 1-19.

Ehnert, I. 2009. Sustainable Human Resource Management. Berlin: Springer.

Ehnert, I., Harry, W. \& Zink, K.J. (Eds.). (2013). Sustainability and human resource management: Developing sustainable business organizations. Springer Science \& Business Media.

European Community (2018). Skills Panorama (Accommodation \& food). Retrieved from: http://skillspanorama.cedefop.europa.eu/bg/sectors/accommodation-food European Community (2018). Eurostat: Tourism industries employment. Retrieved from:

http://ec.europa.eu/eurostat/statistics-explained/index.php/Tourism industries employment

Florida, R. (2014). The Rise of the Creative Class Revisited. New York: Basic Books.

Garavan, T., Heraty, N. \& Morley, M. (1998). Actors in the HRD process: An exploratory study. International Studies of Management \& Organization, 28(1), 114-135.

Gibson, C. (2009). Geographies of tourism: Critical research on capitalism and local livelihoods. Progress in Human Geography, 33(4), 527-534.

Gill, R. \& Pratt, A. (2008). In the social factory? Immaterial labour, precariousness and cultural work. Theory, Culture and Society, 25(7-8), 1-30.

Giousmpasoglou, C., Brown, L., \& Cooper, J. (2018). Alcohol and other drug use in Michelin-starred kitchen brigades. International Journal of Hospitality Management, 70, 59-65. 
Gössling, S., Ring, A., Dwyer, L., Andersson, A. \& Hall, C. (2016). Optimizing or maximizing growth? A challenge for sustainable tourism. Journal of Sustainable Tourism, 24(4), 527-548.

Gursoy, D., Geng-Qing Chi, C. \& Karadag, E. (2013). Generational differences in work values and attitudes among frontline and service contact employees. International Journal of Hospitality Management. 32(1), 40-48.

Homeshaw, J. (1995). Policy community, policy networks and science policy in Australia. Australian Journal of Public Administration, 54(4), 520.

Horemans, J., Marx, I. \& Nolan, B. (2016). Hanging in, but only just: part-time employment and in-work poverty throughout the crisis, Journal of European Labor Studies, 5, 5.

Horney, N. (2016). The gig economy: A disruptor requiring HR agility. People and Strategy 39(3), 20-27.

Hughes, E. \& Scheyvens, R. (2016). Corporate social responsibility in tourism post2015: A Development First approach, Tourism Geographies, 18(5), 469-482 International Labour Organization (2010). Developments and challenges in the hospitality and tourism sector, Geneva: International Labour Office. Retrieved from:

http://www.ilo.org/wcmsp5/groups/public/@ed norm/@relconf/documents/meet ingdocument/wcms 166938.pdf

International Labour Organization (ILO) (2012). Decent work indicators. Concepts and Definitions. Geneva: ILO

International Labour Organization (2016). Key Indicators of the Labour Market (Ninth ed.) Geneva: International Labour Office. Retrieved from:

http://www.ilo.org/wcmsp5/groups/public/---dgreports/--stat/documents/publication/wcms 498929.pdf

International Labour Organization (2018). ILOSTAT. Geneva: International Labour Office. Retrieved from:

http://www.ilo.org/ilostat/faces/ilostathome/download;ILOSTATCOOKIE=32tmgVPUVdWp5qM5Sn4IWqu9MFL3n6x wPBD0Y9m15S04F mrh8ph!1506268203? adf.ctrl$\underline{\text { state }=3 \mathrm{~h} 4 \mathrm{bl1go1} \text { 388\& afrLoop }=684984360524109 \& \text { afrWindowMode }=0 \& \text { afr }}$ Windowld=null 
Jafari, J. \& Scott, N. (2014). Muslim world and its tourisms. Annals of Tourism Research, 44, 1-19.

Janta, H., Ladkin, A., Brown, L. \& Lugosi, P. (2011). Employment experiences of Polish migrant workers in the UK hospitality sector. Tourism Management, 32(5), 1006-1019.

Jones, T., Ram, M. \& Edwards, P. (2004). Illegal immigrants and the informal economy: workers and employer experiences in the Asian underground economy, International Journal of Economic Development, 6(2), 98-119.

Kalleberg, A. (2011). Good Jobs, Bad Jobs: The Rise of Polarized and Precarious Employment Systems in the United States, 1970s to 2000s. New York: Russell Sage Foundation.

King, N. (2004) Using templates in the thematic analysis of texts. In: Cassell C and Symon G (eds) Essential Guide to Qualitative Methods in Organizational Research. London: Sage, 256-270.

Knox, A. (2006). The differential effects of regulatory reform: Evidence from the Australian luxury hotel industry. Journal of Industrial Relations, 48(4), 453-474.

Knox, A. (2014) Human resource management (HRM) in temporary work agencies: Evidence from the hospitality industry, The Economic and Labour Relations Review, 25(1): 81-98.

Knox, A. (2016). Coffee nation: an analysis of jobs in Australia's café industry. Asia Pacific Journal of Human Resources, 54(3), 369-387.

Knox, A., Warhurst, C., Nickson, D. \& Dutton, E. (2015). More than a feeling: using hotel room attendants to improve understanding of job quality. The International Journal of Human Resource Management, 26(12), 1547-1567.

Kotera, Y., Adhikari, P., \& Van Gordon, W. (2018). Motivation Types and Mental Health of UK Hospitality Workers. International Journal of Mental Health and Addiction, https://doi.org/10.1007/s11469-018-9874-z

Kramar, R. (2014). Beyond strategic human resource management: is sustainable human resource management the next approach? The International Journal of Human Resource Management, 25(8), 1069-1089.

Ladkin, A. (2011). Exploring tourism labor. Annals of Tourism Research, 38(3), 11351155. 
Lashley, C. (2009). The right answers to the wrong questions? Observations on skill development and training in the United Kingdom's hospitality sector. Tourism and Hospitality Research, 9(4), 340-352.

Lee, D., Hampton, M. \& Jeyacheya, J. (2015). The political economy of precarious work in the tourism industry in small island developing states, Review of International Political Economy, 22(1), 194-223

Lim, A. (2017). Uber rolls out initiatives to give drivers more choice, flexibility in trips they accept, The Straits Times, $9^{\text {th }}$ November. Retrieved from: http://www.straitstimes.com/singapore/transport/uber-rolls-out-initiatives-togive-drivers-more-choice-and-flexibility-in-trips

Longoni, A. \& Cagliano, R. (2015). Environmental and social sustainability priorities: Their integration in operations strategies, International Journal of Operations and Production Management, 35(2), 216-245.

MacDonald, R. (1994). Fiddly jobs, undeclared working and the something for nothing society. Work, Employment and Society, 8(4), 507-530.

McDowell, L., Batnitzky, A. \& Dyer, S. (2009). Precarious work and economic migration: Emerging immigrant divisions of labour in Greater London's service sector. International Journal of Urban and Regional Research, 33(1), 3-25.

McMillan, C.L., O'Gorman, K.D. \& MacLaren, A.C. (2011). Commercial hospitality: a vehicle for the sustainable empowerment of Nepali women. International Journal of Contemporary Hospitality Management, 23(2), 189-208.

Melissen, F. (2013). Sustainable hospitality: a meaningful notion? Journal of Sustainable Tourism, 21(6), 810-824.

Methven O'Brien, C.M. \& Dhanarajan, S. (2016). The corporate responsibility to respect human rights: a status review, Accounting, Auditing and Accountability Journal, 29(4), 542-567.

Miller, G., Rathouse, K., Scarles, C., Holmes, K. \& Tribe, J. (2010). Public understanding of sustainable tourism. Annals of tourism research, 37(3), 627645.

Mooney, S. (2018). Jobs for the girls? Women's employment and career progression in the hospitality industry. In R. Burke \& J.M. Christensen Hughes (Eds.), Handbook of Hospitality Human Resource Management (pp. 184-215). London and New York: Edward Elgar Publishing. 
Moragra, C. (2017). Nature and Determinants of Informal Employment among Grab and Uber Drivers in Metro Manila, unpublished Master of Industrial Relations thesis, Manila: University of the Philippines Diliman.

Morgan, G., Wood, J. \& Nelligan, P. (2013). Beyond the vocational fragments:

Creative work, precarious labour and the idea of 'Flexploitation'. The Economic and Labour Relations Review, 24(3), 397-415.

Nickson, D., Warhurst, C., Cullen, A.M. \& Watt, A. (2003). Bringing in the excluded? Aesthetic labour, skills and training in the 'new' economy. Journal of Education and Work, 16(2), 185-203.

Orwell, G. (1933). Down and Out in Paris and London, Victor Gollancz: London.

Osnowitz, D. (2010). Freelancing expertise: Contract professionals in the new economy. Ithaca: Cornell University Press.

Poulston, J. (2008). Rationales for employee theft in hospitality: Excuses, excuses. Journal of Hospitality and Tourism Management, 15, 49-58.

Quan, M. (2017). Precarious Work in Europe: Assessing Cross-National Differences and Institutional Determinants of Work Precarity in 32 European Countries. Research in the Sociology of Work, 31, 273-306.

Robinson, R.N.S. (2008). Revisiting hospitality's marginal worker thesis: A monooccupational perspective. International Journal of Hospitality Management, 27(3), 403-413.

Robinson, R.N.S. (2013). Darker still: Present-day slavery in hospitality and tourism services. Hospitality \& Society, 3(2), 93-110.

Robinson, R.N.S., Ritchie, B.W., Kralj, A., Solnet, D.J., Baum, T. \& Ford, R.C. (2014). An Asia-Pacific core-periphery futures paradox: Divergent worker and tourist mobilities. Journal of Travel Research, 53(6), 805-818.

Ross, A. (2009). Nice Work if You Can Get it: Life and Labor in Precarious Times. New York: New York University Press.

Ruhanen, L., Weiler, B., Moyle, B.D. \& McLennan, C.L.J. (2015). Trends and patterns in sustainable tourism research: a 25-year bibliometric analysis. Journal of Sustainable Tourism, 23(4), 517-535.

Santero-Sanchez, R., Segovia-Pérez, M., Castro-Nuñez, B., Figueroa-Domecq, C. \& Talón-Ballestero, P. (2015). Gender differences in the hospitality industry: A job quality index. Tourism Management, 51, 234-246. 
Siebert, S. \& Wilson, F. (2013). All work and no pay: consequences of unpaid work in the creative industries, Work Employment and Society, 27(4), 711-721.

Smith, V. (2010). Enhancing employability: Human, cultural, and social capital in an era of turbulent unpredictability. Human Relations, 63(2), 279-300.

Solnet, D., Nickson, D., Robinson, R.N.S., Kralj, A. \& Baum, T. (2014). Discourse About Workforce Development in Tourism-An Analysis of Public Policy, Planning, and Implementation in Australia and Scotland: Hot Air or Making a Difference? Tourism Analysis, 19(5), 609-623.

Stacey, J. (2015), Supporting Quality Jobs in Tourism, OECD Tourism Papers. Paris: OECD Publishing. Retrieved from: http://www.oecdilibrary.org/docserver/download/5js4rv0g7szren.pdf?expires $=1516774043 \& i d=i d \& a c c n a m e=$ quest $\&$ checksum=CA4983ED67 C6171AB1BA90BB74F74563

Standing, G (2011). The Precariat: The New Dangerous Class. London: Bloomsbury Academic.

The Guardian (2018) Minimum wage: football clubs and Wagamama among worst underpayers. Name and shame list reveals 9,200 underpaid employees within total of 179 firms, $9^{\text {th }}$ March: Retrieved from:

https://www.theguardian.com/society/2018/mar/09/minimum-wage-marriotthotels-and-wagamama-among-worst-underpayers

Timo, N. (1999). Contingent and retentive employment in the Australian hotel industry: Reformulating the core-periphery model. Australian Journal of Labour Economics, 3(1), 47.

The World Bank: IBRD-IDA (2018). Worldbank Indicators. Retrieved from: https://data.worldbank.org/indicator?tab=all

Tribe, J., Dann, G. \& Jamal, T. (2015). Paradigms in tourism research: a trialogue. Tourism recreation research, 40(1), 28-47.

United Nations (2015). Transforming our World: The 2030 agenda for sustainable development. New York: United Nations, Department of Economic and Social Affairs.

Vallance, S., Perkins, H.C. \& Dixon, J.E. (2011). What is social sustainability? A clarification of concepts. Geoforum, 42(3), 342-348.

Vallas, S. \& Prener, C. (2012). Dualism, job polarization, and the social construction of precarious work. Work and Occupations, 39(4), 331-353. 
Wacquant, L. (2014). Marginality, ethnicity and penality in the neo-liberal city: an analytic cartography. Ethnic and Racial Studies, 37(10), 1687-1711.

Wood, R.C. (1992). Deviants and misfits: Hotel and catering labour and the marginal worker thesis. International Journal of Hospitality Management, 11(3), 179-182.

Wood, R.C. (1997). Working in Hotels and Catering. London: International Thomson Business Press.

World Economic Forum. (2016). The future of jobs: Employment, skills and workforce strategy for the fourth industrial revolution. World Economic Forum, Geneva, Switzerland.

WTTC (2015) (2015). Global talent trends and issues for the travel and tourism sector. Oxford, UK: Oxford Economics. Retrieved from: https://www.wttc.org/Imedia/382bb1e90c374262bc951226a6618201.ashx

WTTC (2017). Travel \& Tourism Economic Impact 2017 World. Retrieved from: https://www.wttc.org/-/media/files/reports/economic-impactresearch/regions-2017/world2017.pdf 